\title{
Przerzucanie nadmiernego obciążenia w ramach dochodzenia naprawienia szkody antymonopolowej: dyrektywa, judykatura i wybrane unormowania krajowe**
}

\section{Spis treści}

I. Wprowadzenie

II. Niemcy

1. Regulacja ustawowa

2. Sprawa ORWI: nabywcy pośredni uprawnieni do dochodzenia naprawienia szkody

3. Sprawa Göttingen v. MAN: powodowe gminy nie muszą się obawiać zarzutu passing-on?

III. Wielka Brytania

1. Unormowania ustawowe

2. Sprawa Sainsbury Supermarkets v. MasterCard: wykazanie podwyżki cen na rynku niższego szczebla warunkiem skuteczności passing-on

IV. Hiszpania: sprawa Llace $v$ Volvo/Renault: brak podobieństwa między rynkiem, na jakim doszło do przerzucenia nadmiernego obciążenia a rynkiem skartelizowanym wyklucza passing-on?

V. Holandia: sprawa Tennet v. ABB: skuteczność cywilnoprawnej odpowiedzialności antymonopolowej „wartością cenniejszą” niż unikanie nadmiernego odszkodowania?

VI. Polska

1. Uwagi ogólne (przepisy ustawy)

2. Sprawa kartelu cementowego: „rekompensata” wzrostu cen kartelowych

3. Sprawa opłat za dostęp do infrastruktury kolejowej: zarzut passing-on „zwerbalizowany” w polskim orzecznictwie

VII. Refleksje końcowe

\section{Streszczenie}

W artykule przedstawiono zasady stosowania instytucji przerzucenia nadmiernego obciążenia przez poszkodowanego naruszeniem prawa konkurencji na własnych klientów (tzw. passing-on). Chodzi o zasady wypracowane w orzecznictwie wybranych państw członkowskich, jak też w stosownych (bazujących na dyrektywie 2014/104/UE) przepisach krajowych, przy czym opracowanie koncentrować będzie się przede wszystkim na judykaturze. Przytoczone i skomentowane zostaną wyroki sądów tych państw członkowskich, w których model prywatnego wdrażania prawa konkurencji (także jeszcze przed wejściem w życie ww. dyrektywy) był relatywnie dobrze rozwinięty

\footnotetext{
* Doktor habilitowany, profesor na Wydziale Prawa, Administracji i Stosunków Międzynarodowych Krakowskiej Akademii im. A. Frycza-Modrzewskiego; e-mail: k.kohutek@afm.edu.pl. https://orcid.org/0000-0003-1249-301X.

** Niniejsza publikacja powstała w ramach realizacji projektu badawczego Narodowego Centrum Nauki nr 2017/25/B/HS5/01659.
} 
(jak np. Niemcy, Wielka Brytania). Opracowanie zawiera także odniesienie do wyroków sądów polskich, których wszakże - w obszarze private enforcement (w tym problematyki passing-on) jest bardzo mało.

Słowa kluczowe: przerzucanie nadmiernego obciążenia (passing-on); nabywca pośredni, nabywca bezpośredni; szkoda antymonopolowa; private enforcement; bezpodstawne wzbogacenie.

JEL: K21

\section{Wprowadzenie}

Celem niniejszego opracowania jest przedstawienie zasad stosowania instytucji przerzucenia nadmiernego obciążenia przez poszkodowanego wskutek naruszenia prawa konkurencji na własnych klientów (tzw. zarzut/obrona passing-on). Chodzi o zasady wypracowane w orzecznictwie wybranych państw członkowskich, jak też w stosownych przepisach krajowych. Nacisk położony zostanie na judykaturę, z tego względu, iż instytucji „przerzucenia nadmiernego obciążenia” (the passing on overcharges) poświęcony został (także tak zatytułowany) cały rozdział dyrektywy unijnej ${ }^{1}$. W związku z tym, stosowne uregulowania krajowe - z racji na implementację dyrektywy - są w dużej mierze zbliżone do siebie, a nawet identyczne, nierzadko stanowiąc wierne odzwierciedlenie treści przepisów wspominanej dyrektywy. Jednocześnie - jak dotychczas -wydano zbyt mało wyroków przez sądy państw członkowskich (zwłaszcza orzekających w wyższych instancjach), w których rozpatrywały one sprawę o naprawienie szkody antymonopolowej na podstawie znowelizowanych przepisów krajowych.

W opracowaniu przytoczone zostaną wybrane (zdaniem autora interesujące z perspektywy tytułowej problematyki) wyroki sądów krajowych tych państw członkowskich, w których model prywatnego wdrażania prawa konkurencji (jeszcze przed uchwaleniem dyrektywy odszkodowawczej) był relatywnie dobrze rozwinięty, czyli zwłaszcza Niemcy (którym poświęcono w tym artykule szczególną uwagę), a także Wielka Brytania, Hiszpania i Holandia. W końcowej części artykułu ukazane zostaną także wnioski wynikające z krajowej judykatury dotyczącej problematyki passing-on.

Na wstępie warto wskazać, iż polska ustawa odszkodowawcza ${ }^{2}$ w odniesieniu do problematyki przerzucenia nadmiernego obciążenia zawiera relatywnie wąską (wręcz „skrótową”) regulację. Tymczasem instytucja passing-on ma bardzo istotne znaczenie w zakresie dochodzenia naprawienia tzw. szkody antymonopolowej (w tym zwłaszcza ustalanie jej wysokości, jak i motywacji poszkodowanych do składnia stosownych pozwów). Poprzez to że instytucja ta ma istotny wpływ na wysokość szkody, w dużej mierze determinuje ona zarazem zakres cywilnoprawnej odpowiedzialności antymonopolowej. Jest tak tym bardziej z tego względu, iż, powołanie się na zarzut passing-on może nastąpić zarówno przez sprawcę wspomnianego naruszenia prawa

Dyrektywa Parlamentu Europejskiego i Rady 2014/104/UE z 26 listopada 2014 r. w sprawie niektórych przepisów regulujących dochodzenie roszczeń odszkodowawczych z tytułu naruszenia prawa konkurencji państw członkowskich i Unii Europejskiej, objęte przepisami prawa krajowego (Dz. Urz. UE L 349 z 5.12.2014 r., s. 1); dalej: DD (z angielskiego tzw. Damages Directive) lub dyrektywa odszkodowawcza.

2 Ustawa z dnia 21 kwietnia 2017 r. o roszczeniach o naprawienie szkody wyrządzonej przez naruszenie prawa konkurencji (DzU poz. 1132); dalej, urns lub ustawa odszkodowawcza. 
konkurencji (tzw. defensywne zastosowanie - jako „tarcza”) bądź też przez poszkodowanego, na którego nadmierne obciążenie zostało przerzucone (tzw. ofensywne zastosowanie - jako „miecz”).

\section{Niemcy}

\section{Regulacja ustawowa}

1.1. W Niemczech prawodawca unormował w ustawie antymonopolowej ${ }^{3}$ instytucje przerzucania nadmiernego obciążenia, które - w dosłownym tłumaczeniu - można określić jako „oddalanie/zrzucanie z siebie szkody” (Schadensabwälzung). Instytucję tę reguluje § 33c GWB, zgodnie z którym w przypadku gdy produkt lub usługa została nabyta za „zawyżoną cenę (nadmierne obciążenie)" [überteuerten Preis bezogen (Preisaufschlag)], wówczas powstania szkody nie wyklucza fakt, że produkt ten lub usługa została „odsprzedana” (weiterveräußert). Stosownie do niemieckiej ustawy szkoda poniesiona przez nabywcę powinna zostać uznana za naprawioną - „zrekompensowaną” (ausgeglichen) - w zakresie, w jakim nabywca „przerzucił nadmierne obciążenie wynikające z naruszenia § 33c ust. 1 GWB 4 na swych klientów (nabywców pośrednich)" [an seine Abnehmer (mittelbare Abnehmer) weitergegeben hat]. W moim przekonaniu takie wyraźne unormowanie ustawowe (przynajmniej w oparciu o samo brzmienie powołanego przepisu) wskazuje na brak szkody powoda, o ile tylko skutecznie zastosowany zostanie zarzut passing-on. Jest to wszak podejście dyskusyjne z uwagi na fakt, iż przecież szkoda antymonopolowa po stronie powoda - nawet jeśli w całości przerzuci on nadmierne obciążenie na swych klientów (i zostanie to wykazane) - nadal może występować, przejawiając się w spadku jego sprzedaży wskutek podniesionej ceny (tzw. volume effect) (Bishop i Walker, 2010, s. 700-702; Vejnanovski, 2015). Takie unormowanie jest tym bardziej wątpliwe, gdy weźmie się pod uwagę fakt, iż sam niemiecki prawodawca w swych przepisach dotyczących prywatnego wdrażania prawa konkurencji dostrzega (słusznie!) tenże aspekt szkody. Również w doktrynie zwraca się uwagę na niejasności związane z §33c ust. 1 GWB (Kersting, 2018, s. 149). § 33c GWB w swym ostatnim zdaniu odnosi się także do szkody (możliwej szkody) nabywcy pośredniego polegającej na utracie sprzedaży wynikającej ze wzrostu ceny stanowiącej przerzucenie (całości lub części) nadmiernego obciążania przez tego nabywcę. Zgodnie z § 33c ust. 2 zd.3 GWB prawo poszkodowanego do dochodzenia odszkodowania za "utracony zysk/korzyść” (entgangenen Gewinn) w rozumieniu w $\S 252$ BGB [niemiecki kodeks cywilny] pozostaje bez uszczerbku w zakresie, w jakim ów utracony zysk stanowi skutek przerzucenia nadmiernego obciążenia. Należy jednak wskazać, iż szkoda wynikająca ze spadku sprzedaży (wskutek podwyżki cen zastosowanej przez nabywcę dokonującego przerzucenia) została także wyraźnie wspomniana w dyrektywie. Zgodnie z art. 12 ust. 3 DD, przepisy działu dotyczącego passing-on „pozostają bez uszczerbku dla prawa poszkodowanego do dochodzenia i uzyskania odszkodowania za korzyści utracone w wyniku pełnego lub częściowego przerzucenia nadmiernych obciążeń". Powołany § 33c ust. 2 zd. 3 GWB stanowi więc w zasadzie wierne odzwierciedlenie cytowanego art. 12 ust. 3 DD. Oba przepisy wyraźnie stanowią o szkodzie w postaci utraconych korzyści (a taką postać ma

\footnotetext{
Ustawa z dnia 26.08.1998 r. przeciwko ograniczeniom konkurencji (Gesetz gegen Wettbewerbsbeschränkungen (dalej „GWB”) - w brzmieniu nadanym po nowelizacji z 26.06.2013 r. (BGBI. I S. 1750, 3245) - implementującej dyrektywę odszkodowawczą.

4 Czyli naruszenia niemieckich reguł antymonopolowych lub też art. 101 TFUE i/lub art. 102 TFUE.
} 
właśnie szkoda antymonopolowa wynikająca ze wspomnianego volume effect - w odróżnieniu od szkody występującej w razie całościowego lub częściowego „zaabsorbowania” nadmiernego obciążenia przez nabywcę bezpośredniego (wówczas ma ona postać typowej straty - damnum emergens) ${ }^{5}$.

1.2. Ustawodawca niemiecki - przyznając nabywcy pośredniemu prawo do powołania się na domniemanie, że nadmierne obciążenie zostało na niego przerzucone - wprowadza unormowanie, które w zasadzie ma analogiczne brzmienie (z pewnością co do meritum przesłanek, jakie muszą być spełnione do zastosowania tego domniemania) co art. 14 ust. 2 dyrektywy (zob. § 33c ust. 2 i 3 GWB).

W ostatniej części regulacji poświęconej passing-on, § 33c ust. 5 GWB stanowi, iż przy rozstrzyganiu o zakresie, w jakim nadmierne obciążenie zostało przerzucone, odpowiednie zastosowanie znajduje $§ 287$ niemieckiej procedury cywilnej (Zivilprozessordnung). Przepis ten przyznaje sądowi uprawnienie do ustalenia - wedle własnego uznania oraz „przy uwzględnieniu wszelkich okoliczności" (unter Würdigung aller Umstände) - wysokości szkody, o ile jej istnienie i wysokość jest pomiędzy stornami sporna. W pewnym uproszczeniu powołany przepis stanowi „odpowiednik” polskiego art. 322 k.p.c., który także może mieć (na zasadzie art. 32 polskiej „ustawy odszkodowawczej” ${ }^{6}$ zastosowanie do szacowania przez sąd wysokości przerzucenia nadmiernego obciążenia (Kohutek, 2018, s. 130).

\section{Sprawa ORWI: nabywcy pośredni uprawnieni do dochodzenia naprawienia szkody}

2.1. Niemieckie orzecznictwo jest jednym z pierwszych w UE, w którym wyraźnie potwierdzono możliwości powoływania się na zarzut passing-on, w tym stosowania go w sposób "ofensywny”, czyli przez nabywców pośrednich (Ashton, 2018, s. 60). Miało to miejsce w wyroku Federalnego Trybunału Sprawiedliwości Niemiec (Bundesgerichtshof) z dnia 28 czerwca 2011 r. w sprawie nr KZR 75/10 ORWI7. Także w piśmiennictwie wyrok ten uznaje się za „wyznacznik podejścia Niemiec do problematyki passing-on" (Wieczorek, 2013, s. 36). Sprawa ta dotyczyła naprawienia szkody wyrządzonej wskutek kartelu producentów papieru samokopiującego się (Selbstdurchschreibepapier; carbonless paper) (na jej temat, zob. też Wieczorek, 2013, s. 35-38). Pozew wniesiony został przez przedsiębiorstwo drukarskie, które domagało się odszkodowania w wysokości 223,5 tys. euro. Przedsiębiorstwo to, choć formalnie miało status nabywcy pośredniego, zaopatrując się w papier (nie bezpośrednio od producenta), lecz od hurtowników, to jednak hurtownik ów był spółką w 100\% zależną od producenta (strony kartelu). Można było więc traktować powoda jako de facto nabywcę bezpośredniego, co zarazem pozwoliło przyznać mu - przez (rozpatrujący w drugiej instancji te sprawę) Wyższy Sąd Okręgowy (Oberlandesgericht) w Karlsruhe ${ }^{8}$ - legitymację do wniesienia pozwu w danej sprawie (i zasądzenia na jego rzecz odszkodowania w wysokości 100 tys. euro, czyli nieco więcej niż połowa kwoty jakiej się domagał).

\footnotetext{
Stratę tą stanowi właśnie różnica między ceną, jaką nabywca bezpośredni faktycznie zapłacił a ceną, jaka obowiązywałaby, gdyby nie doszło do naruszenia prawa konkurencji (zob. art. 2 pkt 11 urns - definiujący tak „nadmierne obciążenie”) - pomniejszona o wysokość w jakiej obciążenie to zostało przerzucone przez tego nabywcę (o ile oczywiście doszło do takiego przerzucenia).

6 Ustawa z 21 kwietnia 2017 r. o roszczeniach o naprawienie szkody wyrządzonej przez naruszenie prawa konkurencji (DzU poz. 1132); dalej: urns.

Także w piśmiennictwie wyr. w sprawie ORWI uznaje się za „wyznacznik do podejścia Niemiec do problematyki passing-on” (Wieczorek, 2013, s. 36). OLG Karlsruhe, Entscheidung vom 11.06.2010 - 6 U 118/05 (Kart.) (08).
} 
Trybunał Federalny, choć zaakcentował, że w niemieckim orzecznictwie i literaturze legitymacja czynna nabywców pośrednich jest sporna, to jednak skonkludował, iż podmiotom kupującym (na dalszym szczeblu) towary pochodzące z kartelu przysługuje roszczenie odszkodowawcze (Schadensersatzanspruch) zgodnie z § 823 ust. 2 niemieckiego kodeksu cywilnego ${ }^{9}$ w zw. z art. 101 TFUE $^{10}$ (tym samym takie roszczenie przysługuje mu niezależnie od tego czy zaopatrywał się w towary od podmiotu, który był ekonomicznie zależny - jak w danej sprawie - czy też niezależny od strony kartelu). Swe stanowisko Trybunał uzasadniał m.in. takimi argumentami, iż po pierwsze, „szkodliwie skutki kartelu (bądź też innego zachowania zakazanego na mocy art. 101 TFUE) często nie ograniczają się tylko do strony znajdującej się bezpośrednio na kolejnym szczeblu rynku"11. Po drugie, brak przyznania legitymacji nabywcom pośrednim powodowałby, że w niektórych przypadkach nie byłoby podmiotu zainteresowanego wyegzekwowaniem prywatnoprawnej odpowiedzialności antymonopolowej od sprawców naruszenia; chodzi tu o sytuacje, w których nabywcy bezpośredni sami uzyskiwaliby - „ze względu na zaistniałe okoliczności umowne lub rynkowe" (aufgrund der Vertrags- oder Marktlage) - korzyści ekonomiczne z kartelu. Zdaniem Trybunału mogłoby to mieć miejsce zwłaszcza w przypadku umów typu „koszt -plus" (Kosten-PlusVerträgen) ${ }^{12}$.

Ze stanowiskiem Trybunału należy się zgodzić, tym bardziej, że w praktyce mogą występować także inne okoliczności demotywujące nabywców bezpośrednich do wytaczania pozwów odszkodowawczych ${ }^{13}$, skutkując tym, iż nabywcy pośredni stają się wówczas de facto jedyną grupą podmiotów mogących wyegzekwować cywilnoprawną odpowiedzialność antymonopolową.

Trybunał wskazał również, iż ciężar udowodnienia (tak faktu, jak i wysokości) przerzucenia nadmiernego obciążenia na nabywcę pośredniego spoczywa na tym podmiocie, który na to się powołuje ${ }^{14}$. Obecnie niemiecka ustawa przyznaje nabywcy pośredniemu domniemanie, że nadmierne obciążenie zostało na niego przerzucone, pod warunkiem spełnienia trzech przesłanek zawartych w $\S 33 c$ ust. 2 GWB (stanowiących w zasadzie odwzorowanie warunków z art. 14 ust. 2 dyrektywy).

2.2. W wyroku w sprawie ORWI Trybunał bliżej zajął się także problematyką przyczynowości (Ursächlichkeit) wzrostu cen poprzedzonego zmową. W tym zakresie wskazał na kilka istotnych wątków. Zwrócił uwagę, iż z uwagi na „złożoność ekonomicznych czynników mających wpływ na kształtowanie się cen" (ökonomischen Komplexität der Preisbildung) na rynku nie można przyjąć domniemania, iż „pozostającą w związku czasowym z kartelem podwyżkę cen na innym rynku należy przypisywać kartelowi”" ${ }^{15}$. Dalej wskazał, iż na kształtowanie się cen

\footnotetext{
9 Przepis ten stanowi podstawę dochodzenia deliktowej odpowiedzialności w prawie niemieckim, będąc - w pewnym uproszczeniu - „odpowiednikiem" naszego art. 415 k.c.

10 Pkt 24 i 25 wyr. Trybunału w sprawie ORWI

11 Die schädlichen Wirkungen eines Kartells oder eines sonstigen nach Art. 101 AEUV verbotenen Verhaltens bleiben häufig nicht auf die unmittelbare Marktgegenseite begrenzt; pkt 26 wyr. Trybunału w sprawie ORWI.

12 Są to umowy, w których nabywca bezpośredni (klient naruszyciela) ma zagwarantowany określony poziom marży niezależnie od wysokości jego kosztów (jakie sam ponosi ze swymi dostawcami/producentami). Tym samym, jeśli koszty te wzrastają (np. wskutek kartelu), wówczas jednocześnie (na mocy tak skonstruowanej umowy) odpowiednio wzrasta poziom marży zbywcy; zob. pkt 33 wyr. Trybunału w sprawie ORWI.

$13 \mathrm{~Np}$. obawa przed pogorszeniem relacji biznesowych ze swym dostawcą (a nawet ich zerwanie przez pozwanego dostawcę), czy też brak czysto finansowych bodźców (w szczególności wskutek znacznego lub całościowego przerzucenia nadmiernego obciążenia przez nabywcę przy zachowaniu dotychczasowego poziomu sprzedaży).

14 Die Darlegungslast dafür, dass und gegebenenfalls in welcher Höhe ein kartellbedingter Preisaufschlag auf die nachfolgende Marktstufe abgewälzt wurde, trägt der indirekte Abnehmer, der sich hierauf beruft; pkt 44 wyr. Trybunału w sprawie ORWI.

15 Eine im zeitlichen Zusammenhang mit dem Kartell auftretende Preiserhöhung auf den Anschlussmärkten ursächlich auf das Kartell zurückzuführen ist; pkt 45 wyroku w sprawie ORWI.
} 
ma wpływ wiele czynników struktury rynkowej oraz przyjętej strategii handlowej. Dlatego też nie jest wystarczające wykazanie, iż także na danym rynku doszło do wzrostu cen w czasie kartelu. Konieczne jest stwierdzenie, iż „wzrost cen nastąpił wskutek kartelu a nie innych czynników”16. Może się bowiem okazać, że ceny stosowane przez nabywcę nie będą kształtowane (w tym zwłaszcza podwyższane) wskutek kartelu, lecz ich poziom wynikać będzie z innych niezależnych czynników rynkowych (jak np. elastyczność cenowa podaży lub popytu, czas trwania naruszenia oraz intensywność konkurencji na danym rynku/szczeblu tego rynku ${ }^{17}$ ).

\subsection{Spostrzeżenia niemieckiego Trybunału są trafne i mają zarazem „,szersze zasto-} sowanie", tj. nie ograniczają się tylko do interpretacji przesłanki związku przyczynowego, lecz odnoszą się także do wysokości samej szkody antymonopolowej, a co za tym idzie także do ustalania czy i w jakim zakresie doszło do przerzucenia nadmiernego obciążenia i/lub spadku sprzedaży po stronie powoda (wspomniany wyżej volume effect). Takie czynniki, jak zwłaszcza intensywność konkurencji na rynku na jakim miałoby dojść tego przerzucenia takiego obciążenia, w tym także stopień koncentracji tegoż rynku często mają wpływ na to czy w ogóle, a jeśli tak to w jakim zakresie możliwe (realne) jest takie przerzucenie (zob. też Turno 2018, s. 172, 173).

Dopóki więc polska judykatura (lub sądy unijne ${ }^{18}$ ) nie dadzą bliższych wskazówek w tej materii, argumenty Trybunału mogą pomocniczo stanowić pewien punkt odniesienia dla rozstrzygania (interpretowania) spraw o szkodę antymonopolową. Jakkolwiek sporo wskazówek (a nawet kazuistycznych wyjaśnień) zawartych zostało w aktach prawa miękkiego wydanych przez Komisję Europejską (w tym wytyczne do jakich expressis verbis odsyła art. 31 ust. 2 urns). Przepis ten upoważnia sądy do kierowania się (,posiłkowania”) przy ustalaniu wysokości szkody antymonopolowej po pierwsze, wytycznymi zawartymi w komunikacie Komisji 2013/C 167/0719 oraz wytycznymi Komisji Europejskiej, o których mowa w art. 16 DD. W kontekście tematyki niniejszego opracowania znacznie mają zwłaszcza te drugie. Zgodnie z powołanym przepisem, Komisja wydaje wytyczne dla sądów krajowych, w których wskazuje, jak szacować część nadmiernego obciążenia przerzuconą na nabywcę pośredniego. W sierpniu 2019 r. Komisja wydała takie wytyczne 20 .

2.4. Innym - jakkolwiek wartym tylko krótkiego wspomnienia - orzeczeniem jest wyrok Sądu Okręgowego (Landesgericht) w Düsseldorfie z 2015 roku ${ }^{21}$ (sprawa kartelu szyb samochodowych). Wyrok ten w kluczowych fragmentach literalnie opiera się na spostrzeżeniach niemieckiego Trybunału w sprawie ORWI. W punkcie 227 wprost odnosi się do zarzutu passing-on, rozwijając stosowną argumentację w punkcie 228 (który ma identyczną treść z punktami 45-48 wyroku w sprawie ORWI). Wyrok w sprawie kartelu szyb samochodowych wprost posługuje się terminem (passing-on) i nawiązuje także do samej dyrektywy 22 (co z uwagi na datę swego wydania nie mogło mieć miejsca w wyroku Bundesgerichtshof w sprawie ORWI).

\footnotetext{
6 Preiserhöhung gerade auf das Kartellgeschehen und nicht etwa auf andere preisbildende Faktoren zurückgeht; pkt 46 wyr. w sprawie ORWI.

Preiselastizität von Angebot und Nachfrage, die Dauer des Verstoßes sowie die Intensität des Wettbewerbs auf der Stufe; ibidem.

18 Jakkolwiek pewne wskazówki w zakresie wykładni interpretacji związku przyczynowego wynika z wyr. Trybunału z dnia 5.06 .2014 r. w sprawie C557/12 Kone i inni v. ÖBB-Infrastruktur AG, ECLI:EU:C:2014:1317.

19 Komunikat w sprawie ustalania wysokości szkody w dochodzeniu roszczeń odszkodowawczych z tytułu naruszenia art. 101 lub art. 102 Traktatu o funkcjonowaniu Unii Europejskiej (Dz. Urz. UE C 167 z 13.06.2013, str. 19).

20 Chodzi o Komunikat Komisji: „Wytyczne dla sądów krajowych dotyczące sposobu szacowania, jaka część nadmiernego obciążenia została przerzucona na nabywcę pośredniego" (2019/C 267/07); Dz. Urz. UE z 9.08.2019 r. (C 267/4).

21 Wyr. SO (Landgericht) w Düsseldorfie, 14d O 4/14 z dnia 15.11.2015 r. (ECLI:DE:LGD:2015:1119.14D.O4.14.00).

22 Jakkolwiek - w kontekście długości całego orzeczenia - relatywnie krótko (zob. pkt 223 tego wyroku).
} 


\section{Sprawa Göttingen v. MAN: powodowe gminy nie muszą się obawiać zarzutu passing-on?}

3.1. Godny uwagi jest także wyrok Sądu Rejonowego w Hanowerze z dnia 28 grudnia 2017 roku $^{23}$. W sprawie tej niemiecka gmina miejska wniosła pozew odszkodowawczy przeciwko MAN Truck \& Bus Deutschland $\mathrm{GmbH}$, domagając się naprawiania szkody w wysokości ponad 335 tys. euro. Szkoda polegała na zakupie przez tę gminę 13 ciężarówek (do czyszczenia miasta lub straży pożarnej). Powódka powołała się na klauzulę zawartą w umowie, zgodnie z którą należy się jej 15\% sumy umownej w przypadku dopuszczenia się przez drugą stronę (pozwanego) praktyk antykonkurencyjnych. Sąd podzielił stanowisko powodowej gminy (uznając zarazem także taką - zryczałtowaną/umowną - kwotę odszkodowania za słuszną, niewygórowaną), stając się zarazem pierwszym przypadkiem zasądzenia w Niemczech odszkodowania za szkodę wynikającą z tzw. kartelu ciężarówek ${ }^{24}$ (wyrok ów nie jest wszak prawomocny, gdyż MAN złożył odwołanie ${ }^{25}$ ).

Najistotniejszym w kontekście tematyki niniejszego opracowania jest fakt, iż w powyższej sprawie sąd odniósł się także do „zarzutu passing-on” (passing-on-Einwand). Uznał, iż z zasady roszczenie odszkodowawcze powodowej gminy nie odpada na tej podstawie, iż pozwany podniósł taki zarzut, przejawiający się w przerzuceniu przez gminę podwyższonej ceny ciężarówek na mieszkańców (płacących lokalne podatki lub inne opłaty gminne). Sąd w Hanowerze powołał się na (cyt. wyżej) wyrok BGH w sprawie ORWl; zdaniem (tego pierwszego) sądu aby przyjąć, że doszło (mogło dojść) do „przerzucenia wywołanej kartelem podwyżki cen” (Abwälzung der kartellbedingten Preiserhöhung) powinien „istnieć jakiś rynek niższego szczebla” (das Vorliegen eines Anschlussmarkts), na którym występuje konkurencja czy to po stronie podażowej, czy to popytowej; tymczasem w ocenianej sprawie „brak jest takiej aktywności rynkowej na dalszym szczeblu rynku" (ist aber kein solches Marktgeschehen auf einem Folgemarkt ersichtlich). Istotnie w sprawie tej podmiotem poszkodowanym kartelem była gmina świadcząca usługi (czyszczenie miasta i utylizacja śmieci) na rzecz swych mieszkańców (zatem nie na rzecz podmiotów działających na określonym rynku niższego szczebla objętym procesem konkurencjie6).

3.2. Choć wyrok w sprawie Göttingen nie jest prawomocny, to jednak - w razie podzielenia tego stanowiska przez sądy wyższych instancji (tym bardziej przez BGH) - jego konsekwencje mogą być daleko idące. Oznaczałyby one bowiem, że gminy (inne jednostki samorządu terytorialnego), a być może i wszelkie inne podmioty, które w założeniu nie prowadzą działalności gospodarczej (nie oferują towarów/usług na rynku, a zatem także na jego dalszym szczeblu) nie musiałyby się obawiać „ubezskutecznienia” ich pozwów odszkodowawczych poprzez zarzut (obronę) passing -on ze strony pozwanego. Ma to spore znaczenie praktyczne, jako że gminy (inne podmioty nie prowadzące działalności gospodarczej) nierzadko są klientami naruszycieli reguł antymono-

\footnotetext{
Wyr. Sądu Rejonowego w Hanowerze (Landgericht Hannover) (18 O 8/17), dostępny w całości na stronie: https://www.staedteverband-sh.de/ nneres/aid/2470.

24 Chodzi o kartel (polegający głównie na uzgodnieniu cen) zawarty miedzy producentami ciężarówek o wadze 6-16 i powyżej 16 ton (MAN, Volvo/ Renault, Daimler, Iveco, DAF, SCANIA) w okresie pomiędzy 1997 a 2011 r. W swej decyzji (z dnia 19.07.2016 r. w sprawie nr AT 39824), Komisja nałożyła na sprawców tego naruszenia kary o rekordowo wysokiej (łącznej) wysokości niepełna 3 mln euro.

25 Zob.: LKW-Kartell: Erstes Urteil zugunsten einer Kommune. Update zur Entwicklung einer Rechtsprechung (https://publicus.boorberg.de/ Ikw-kartell-erstes-urteil-zugunsten-einer-kommune).

26 Takowa konkurencja nie występuje oczywiście pomiędzy użytkownikami (Benutzer) - tj. mieszkańcami gminy - którzy nie rywalizują miedzy sobą o usługi czyszczenia miasta (co także zaakcentował sąd w Hanowerze).
} 
polowych ${ }^{27}$; ci pierwsi są zarazem potencjalnymi powodami w procesach odszkodowawczych, a interpretacja jaka przyjęta została w sprawie Göttingen może stanowić dodatkową „zachętę” do dochodzenia przez nich odszkodowania. Powołane stanowisko sądu w Hanowerze wydaje się być merytorycznie uzasadnione, mogąc tym samym znaleźć aprobatę także w innych sprawach lub - w innych państwach członkowskich (w tym w Polsce) - o naprawienie szkody antymonopolowej wnoszonych przez takie „niekomercyjne” jednostki.

\section{Wielka Brytania}

\section{Unormowania ustawowe}

1.1. Prawo brytyjskie zawiera relatywnie szczegółowe regulacje dotyczące passing-on (tak też literalnie tytułuje stosowne przepisy). W pierwszej kolejności warto wskazać na szeroki zakres definicyjny „przerzucenia” szkody antymonopolowej na inne podmioty, jakie prawo to ustanawia, wyróżniając nie tylko nadmierne obciążenie (overcharge) jako skutek naruszenia prawa konkurencji (prowadzący do podwyższenia ceny w porównaniu do tej jaka zostałaby zapłacona w razie braku naruszenia), lecz także tzw. niedopłatę (underpayment). Ta druga sytuacja zachodzi „w przypadku gdy wskutek dostarczenia produktu lub usługi naruszycielowi, faktycznie zapłacona cena jest niższa niż kwota, która zostałaby zapłacona w przypadku braku naruszenia"28. W odróżnieniu więc od typowego przypadku nadmiernego obciążenia (przerzucanego niejako w dół rynku - downstream), zastosowanie niedopłaty następuje „w górę rynku” (upstream). Jej istotą jest niejako „wymuszenie” na swych dostawcach przez kontrahenta naruszyciela obniżenia ceny, jaką dotychczas kontrahent ów im płacił. W zależności od wysokości tego obniżenia możliwym zatem będzie przypadek, że dzięki tego rodzaju niedopłacie (zaoszczędzeniu) przez kontrahenta naruszyciela podwyższona wskutek naruszenia prawa konkurencji cena produktu/usługi (nabywanego/ świadczonej na mocy kontraktu z naruszycielem) zostanie w całości lub w części przerzucona na dostawców tegoż kontrahenta.

Warto zwrócić uwagę, że przepisy samej dyrektywy, choć nie posługują się terminem niedopłaty (lub podobnym), zwierają unormowanie, które nakazuje odpowiednie stosowanie przepisów rozdziału o przerzucaniu nadmiernego obciążenia "gdy naruszenie prawa konkurencji jest związane $z$ dostawami na rzecz sprawcy naruszenia" (the infringement of competition law relates to a supply to the infringer) (zob. art. 12 ust. 4 DD). Dotyczy to właśnie przypadku, w którym ofiarą naruszenia nie jest nabywca, lecz dostawca sprawcy, a szkoda dostawcy polega właśnie na uzyskaniu od swych klientów (sprawców naruszenia) niższej ceny niż ta jaka by obowiązywała w razie braku naruszenia. Takie stanowisko potwierdza sam prawodawca unijny, wskazując, że naruszenie może również dotyczyć dostaw realizowanych na rzecz sprawcy naruszenia (np. w przypadku kartelu nabywców). W takich przypadkach strata rzeczywista mogłaby wynikać z faktu zapłacenia przez sprawców naruszenia niższej ceny swoim dostawcom. Następnie dodaje wprost, iż niniejsza dyrektywa, a szczególnie zasady dotyczące przerzucania obciążeń, powinna być odpowiednio

\footnotetext{
27 Przy czym mogą to być także naruszenia „niekartelowe” - ale w szczególności tzw. nadużywanie pozycji dominującej poprzez tzw. praktyki eksploatacyjne (polegające np. na narzucaniu przez dominanta cen znacznie wygórowanych) (zob. Kohutek, 2018, s. 142, 143).

28 When a product or service is provided directly to the infringer, the price actually paid is less than the amount that would have been paid in the absence of the infringement; zob. sekcja 47F pkt 8 lit. b brytyjskiej ustawy o konkurencji (Competition Act z 1998 r.) - dalej: CA - znowelizowanej w 2017 r. poprzez dodanie sekcji 47F dotyczącej roszczeń dotyczących szkód wynikających z naruszenia prawa konkurencji (The Claims in respect of Loss or Damage arising from Competition Infringements). Pozyskano z: www.legislation.gov.uk.
} 
stosowana do tych przypadków (motyw 43 preambuły do DD). Brytyjskie prawo konkurencji jest więc jednym z nielicznych unormowań z państw członkowskich, które wprost (expressis verbis) implementuje rozwiązanie o jakim mowa w powołanym at. 12 ust. 4 DD. Należy jednak dodać, iż brak wyraźnych przepisów dotyczących przypadku opisanego wyżej (zob. motyw 43 preambuły), w większości innych porządków prawnych państw członkowskich (w tym Polski) nie może być odczytywany jako brak obowiązywania tam rozwiązania dotyczącego przerzucania (całości lub części) szkody antymonopolowej - w postaci niedopłaty - „w górę rynku”. Świadczyć o tym może chociażby ustawowe zdefiniowanie dostawcy bezpośredniego i pośredniego (w polskiej ustawie w art. 2 pkt 15 i 16 urns); przeciwne rozwiązanie byłoby nadto niezgodne z dyrektywą.

1.2. Defensywny aspekt stosowania zarzutu passing-on unormowany został w art. 47F pkt 11 CA. Przepis ów z resztą wprost stanowi, iż ma on zastosowanie do przypadku, kiedy pozwany „w ramach swej obrony podnosi, iż powód przerzucił w całości lub w części nadmierne obciążenie lub niedopłatę na inną osobę" (in its defence, the defendant claims that the claimant passed on all or part of the overcharge or underpayment to another person). W takim przypadku na pozwanym spoczywa ciężar udowodnienia, iż: (a) powód przerzucił nadmierne obciążenie lub niedopłatę oraz (b) „zakres w jakim powód to uczynił” (the extent to which the claimant did so). Powołane unormowania nie pozostawia więc wątpliwości, iż pozwany musi udowodnić samą wysokość nadmiernego obciążenia, w jakim zostało ono przerzucone przez powoda (o czym stanowi - jedynie preambuła dyrektywy; zob. motyw 39). Z kolei ofensywny aspekt stosowania zarzutu passing-on zawarto w art. 47F pkt 9 CA. Przepis ten nakazuje traktować, iż powód (w danym wypadku nabywca pośredni) jest uznawany jako ten, który wykazał, że nadmierne obciążenie zostało na niego przerzucone, w przypadku spełnienia przesłanek (w zasadzie literalnie) odpowiadających tym z art. 14 ust. 2 DD.

\section{Sprawa Sainsbury Supermarkets v. MasterCard: wykazanie podwyżki cen na rynku niższego szczebla warunkiem skuteczności passing-on}

2.1. W brytyjskim porządku prawa konkurencji wyrok w sprawie Sainsbury Supermarkets v. MasterCard ${ }^{29}$ jest pierwszym orzeczeniem, w którym stwierdzona została możliwość powoływania się na zarzut przerzucania nadmiernego obciążenia (Veljanovski, 2017). Co więcej, w tym rozbudowanym wyroku (ponad 300 stron) sąd relatywnie szczegółowo opisał przesłanki jakie jego zdaniem należy wykazać, aby skutecznie skorzystać z tzw. passing-on defence. W związku z tym, uważam, że - zwłaszcza w kontekście problematyki niniejszego opracowania - wyrok ów jest bardziej interesujący niż przepisy samej brytyjskiej ustawy o konkurencji (które determinowane są przecież powszechnie znanymi rozwiązaniami z dyrektywy).

Sainsbury to podmiot prowadzący sieć supermarketów. Wytoczył pozew przeciwko MasterCard z zarzutem naruszenia przez tego drugiego przedsiębiorcę krajowego prawa konkurencji polegającego na narzucaniu nadmiernie wygórowanych cen (excessive prices) za transakcje realizowane za pomocą kart płatniczych (tzw. opłatę interchange) ${ }^{30}$. Sainsbury domagał się odszkodowania za szkodę, jaką poniósł w wyniku uiszczania na rzecz MasterCard zawyżonych opłat interchange.

\footnotetext{
29 Wyr. Trybunału ds. Konkurencji (Competition Appeal Tribunal) z 14.07.2016 r. w sprawie nr 1241/5/7/15 (T); dalej: CAT.

30 Opłata interchange to kwota pobierana od agenta rozliczeniowego (zwanego też acquirerem - jakim w praktyce acquirerami są głównie banki), tj. podmiotu obsługującego transakcję dokonaną tą kartą płatniczą od akceptanta karty (np. sklepu, stacji paliw, hotelu, restauracji, itp.) oraz przetransferowywania do banku (emitenta - wydawcy karty) (zob. też np. Kaszubski i Obsejda, 2012, s. 110).
} 
Ten drugi przedsiębiorca podniósł wszak, iż Sainsbury faktycznie nie doznał szkody, gdyż przerzucił na własnych klientów nadwyżkę (overcharge) wynikającą z zawyżonej opłaty, jaka naliczana została przez Mastercard. Trybunał stwierdził, iż MasterCard dopuścił się naruszenia krajowego prawa konkurencji ${ }^{31}$ oraz zasądził na rzecz Sainsbury odszkodowanie. Co istotne uznał, że - jako zasada - zarzut passing-on jest dopuszczalny ${ }^{32}$ w brytyjskim prawie konkurencji (co zarazem nie może budzić wątpliwości w kontekście rozwiązań z dyrektywy); skonstatował wszak, iż w danej sprawie zarzut ów należy z przyczyn dowodowych odrzucić. Zdaniem Trybunału, „podniesiona przez MasterCard obrona passing-on jest nieskuteczna. Nie stwierdzono zauważalnego wzrostu ceny detalicznej, tym bardziej takiego, który jest przyczynowo związany z opłatą interchange stosowaną w Wielkiej Brytanii. MasterCard nie może również zidentyfikować żadnego nabywcy lub klasy nabywców Sainsbury, na których przerzucono nadmierne obciążenie, którzy byliby w stanie dochodzić odszkodowania"33.

2.2. Jak już wyżej wspomniano, w wyroku w sprawie Sainsbury Trybunał wypracował przesłanki, jakie powinny zostać łącznie spełnione, aby pozwany mógł skutecznie powołać się na zarzut passing-on (określany jako tzw. dwuetapowy test prawny obrony passing-on (two-part legal test for the pass-on defence) (Veljanovski 2017), przy czym jednocześnie Trybunał zwrócił uwagę na różnice zachodzące w prawnym i ekonomicznym pojmowaniu zjawiska passing-on. Zdaniem Trybunału, pozwany musi udowodnić, iż: po pierwsze, nastąpiła „identyfikowalna” (identifable) podwyżka cen stosownych przez nabywcę pozostająca w związku przyczynowym (causally conected) z nadmiernym obciążeniem (overcharge) oraz, po drugie, istnieje pewna grupa powodów działających na rynku niższego szczebla (class of claimants), która zapłaciła podwyższoną cenę. Jak to wskazał Trybunał, „o ile ekonomista może definiować zjawisko passing-on znacznie szerzej (np. uwzględniając także oszczędności kosztowe i obniżone wydatki), obrona passing-on wiąże się wyłącznie z identyfikowalną podwyżką cen zastosowaną przez przedsiębiorcę wobec swych klientów"34. Z jednej strony takie wąskie (tzw. prawne) ujęcie zakresu definicyjnego passing-on (jakie przyjął CAT) zasługuje na aprobatę przede wszystkim z tego względu, iż w mojej ocenie zarzut ów powinien być - w przypadku gdy jest podnoszony przez sprawcę naruszenia prawa konkurencji - stosowany restrykcyjnie (w odniesieniu do przesłanek jego dopuszczalności/skuteczności; szerzej o tym: Kohutek, 2020). Z drugiej zaś - brytyjski prawodawca jest jednym z nielicznych (o ile nie jedynym), który wyraźnie ustawowo nadał relatywnie szeroki zakres definicyjny zarzutowi passing-on (jako underpayment), pozwalając obejmować nim nie tylko podwyżkę cen (overcharge), lecz także „oszczędności”, jakie uzyskał dany podmiot (tu ofiara naruszenia będąca dostawcą sprawcy - dostawca bezpośrednim) dzięki zredukowaniu ceny płaconej na rzecz swych własnych dostawców (dostawców pośrednich).

\footnotetext{
31 Naruszenie takie nie zostało bowiem wcześniej stwierdzone przez organ antymonopolowy (było to zatem pozew stand-alone). Należy to odróżnić od tzw. pozwów (spraw) follow-on, czyli wytaczanych po tym jak naruszenie prawa konkurencji zostało stwierdzone przez ów organ (w tym Komisję Europejską).

32 Jako zasada zarzut ów został bowiem uznany za dopuszczalny przez CAT; w szczególności sąd uznał, iż Sainsbury - jako nabywca pośredni - jest podmiotowo uprawniony do dochodzenia odszkodowania (ma legitymację czynną).

33 Jak to wskazał CAT, MasterCard's pass-on defence must fail. No identifiable increase in retail price has been established, still less one that is causally connected with the UK MIF. Nor can MasterCard identify any purchaser or class of purchasers of Sainsbury's to whom the overcharge has been passed who would be in a position to claim damages; zob. pkt 485 wyr. w sprawie Sainsbury.

34 Whereas an economist might well define pass-on more widely (i.e. to include cost savings and reduced expenditure), the pass-on defence is only concerned with identifiable increases in prices by a firm to its customers; pkt 484 wyr. w sprawie Sainsbury.
} 


\section{Hiszpania: sprawa Llace v. Volvo/Renault: brak podobieństwa między rynkiem, na jakim doszło do przerzucenia nadmiernego obciążenia a rynkiem skartelizowanym wyklucza passing-on?}

1. W Hiszpanii (jeszcze przed implementacją dyrektywy odszkodowawczej) orzecznictwo aprobowało powoływanie się na zarzut passing-on ${ }^{35}$. Obecnie w art. 78-80 ustawy o konkurencji (w brzmieniu nadanym dekretem królewskim 9/2017 z 26 maja 2017 r.) „,normatywnie potwierdzono" możliwość podniesienia przez pozwanego wspomnianego zarzutu, wskazując zarazem, iż to na nim spoczywa ciężar dowodu. Hiszpania - podobnie jak Niemcy - jest państwem, w którym znaczna część pozwów odszkodowawczych wytaczana jest dla naprawienia szkody wynikającej z kartelu ciężarówek. W hiszpańskich sądach jest obecnie około 90 spraw odszkodowawczych przeciwko członkom kartelu ciężarówek (domagających się naprawienia szkody za zakup - łącznie - ponad 1500 pojazdów po „kartelowo” zawyżonych cenach (Kulikowska-Wielgus, 2019). W ramach tego opracowania można wskazać jedynie krótko na dwie sprawy. W pierwszej z nich sąd nie kwestionował zasadności pociągnięcia do odpowiedzialności spółki zależnej - tj. Volvo Group España S.A. - od uczestnika kartelu, tj. Volvo/Renault; sąd za przeszkodę w zasadności pozwu, a także zasądzenia odszkodowania od ww. podmiotu (w kwocie 128 756,00 euro) nie uznał faktu, iż w trakcie naruszenia podmiot ów formalnie nie istniał, jednakże jest jego (tj. Renault Trucks España S.L.) następcą prawnym ${ }^{36}$ (z czym należy się zgodzić, zwłaszcza w kontekście szerokiego zakresu podmiotowego odpowiedzialności antymonopolowej; zob. też np. Kohutek, 2019, s. 38-45).

2. W kontekście omawianej tematyki istotna jest zwłaszcza druga ze wspomnianych spraw (również wniesiona przeciwko Volvo/Renault). Zainicjowana ona została przez Llacer - firmę transportu drogowego towarów z siedzibą w Walencji. W sprawie tej pozwany podniósł, iż firma ta nie poniosła szkody, gdyż przerzuciła podwyższone wskutek kartelu ceny zakupu ciężarówek na swych klientów (tj. korzystających z usług transportowych). Sąd Handlowy w Walencji uznał, że na passing-on defence nie można powołać się odniesieniu do rynku (na jakim działają podmioty, na które przerzucono nadmierne obciążenie), czyli - w danej sprawie - był to rynek usług transportowych, w sytuacji kiedy rynek ów nie jest podobny do rynku skartelizowanego (rynek sprzedaży samochodów ciężarowych). Sąd wyjaśnił, że w prawie hiszpańskim unormowanie dotyczące zarzutu (obrony) przerzucenia nadmiernego obciążenia stanowi o „łańcuchu dostaw" (supply chain/cadena de suministro) ${ }^{37}$, który - zdaniem sądu - należy interpretować jako ograniczające tę obronę (zarzut) jedynie do rynków wertykalnych (vertical markets), które są podobne do produktów oferowanych na rynku skartelizowanym (tj. ciężarówki). Przeciwnie, obrona jest niedopuszczalna w przypadku rynków pozbawionych tego podobieństwa (usługi transportowe $)^{38}$.

\footnotetext{
35 Zob. zwłaszcza wyr. hiszpańskiego Sądu Najwyższego z 7.11.2013 r. w sprawie nr 5819/2013, Nestle i inni v. Ebro Puleva.

36 Zob. wyr. Sądu Handlowego w Murcji z 26.09.2018 r. oraz przede wszystkim wyrok tegoż sądu z dnia 18.10.2018 r.; zob. też First Spanish Judgments in trucks cartel follow-on actions (www.carteldamageclaims.com).

37 Zob. art. 80 ustawy z 3 lipca 2007 o ochronie konkurencji (znowelizowanej dnia 27 maja 2017 r. poprzez wprowadzenie unormowań działu tej ustawy dotyczących „odszkodowania za szkody wyrządzone wskutek praktyk ograniczających konkurencję) [De la compensación de los daños causados por las prácticas restrictivas de la competencia], który pozwala na wniesienia pozwu także przez podmiot, który doznał szkody wskutek naruszenia, lecz prowadzi działalność na „innym poziomie łańcucha dostaw” (otros niveles de la cadena de suministro).

38 Zob. orzeczenie (zarządzenie) Sądu Handlowego w Walencji z 17.12.2018 r. w sprawie 309/2018 oraz Contreras, 2018.
} 
3. Z zajętym przez sąd w Walencji stanowiskiem (zob. wyżej wytłuszczony fragment) trudno się zgodzić. Po pierwsze, dopuszczalność zarzutu passing-on nie jest zależna od tego czy klient poszkodowanego prowadzi działalność na podobnym (lub w inny sposób powiązanym) rynku, na jakim doszło do naruszenia prawa konkurencji (tu zwłaszcza zawarcia kartelu). Inna sprawa, że w praktyce rynki te są ze sobą ekonomicznie powiązane i w tym sensie „podobne”39. Przede wszystkim wszak po drugie, kierując się samą preambułą dyrektywy można by wskazywać, iż w ogóle rynek, na jakim oferowany jest produkt skartelizowany nie musi być w jakikolwiek sposób (ekonomicznie) podobny do rynku, na jakim zbywa swe produkty (świadczy usługi) nabywca bezpośredni lub pośredni. Wystarczającą zaś przesłanką powołania się na zarzut passing-on jest sam fakt, iż nabywca bezpośredni przerzucił nadmierne obciążenie na „swoich własnych nabywców" (to its own purchasers) (zob. motyw 39 preambuły do dyrektywy). Jednocześnie nie można pominąć przepisów samej dyrektywy; z tych zaś wynika, iż oba wspomniane wyżej rynki powinny pozostawać w relacji „łańcucha dostaw” (supply chain) (zob. pkt 12 ust. 2 DD). Oznacza to, że owszem zastosowanie przedmiotowego zarzutu nie jest całkowicie nieograniczone w kontekście rynków, jakie bierze się pod uwagę, jednakże warunek pozostawania tych rynków we wspomnianej wyżej relacji należy interpretować szeroko. Świadczy o tym w szczególności definicja nabywcy pośredniego jako podmiotu, który zakupił od nabywcy bezpośredniego „skartelizowany/ną” produkt (usługę), ale także produkt (usługę) „będący pochodnymi takich produktów lub usług, lub zawierające takie produkty lub usługi" 40 .

Odnosząc to do sprawy rozpatrywanej przez sąd w Walencji o podobieństwie rynków (w rozumieniu takich, które pozostają ze sobą w relacji łańcucha dostaw), należy mówić nie tylko wówczas, gdy nabywca bezpośredni jest hurtownikiem (tj. tak jak sprawca kartelu zajmuje się podobną działalnością tj. sprzedażą ciężarówek), lecz także wtedy, gdy sam wykorzystuje nabyty produkt/usługę w ramach własnej oferty handlowej na rynku jakim działa - czyli danej sprawie nie sprzedaje (odsprzedaje) tych ciężarówek, lecz świadczy z ich wykorzystaniem własne usługi transportowe (co stanowi przedmiot jego działalności gospodarczej na rynku - będącym rynkiem pozostającym w wertykalnej relacji, tj. jako „łańcucha dostaw”, o jakim wspomina dyrektywa). Na poparcie można też przytoczyć stanowisko Komisji zajęte w odniesieniu do pojmowania relacji wertykalnej ${ }^{41}$.

\section{Holandia: sprawa Tennet v. ABB:}

\section{skuteczność cywilnoprawnej odpowiedzialności antymonopolowej „wartością cenniejszą" niż unikanie nadmiernego odszkodowania?}

1. W prawie holenderskim instytucja passing-on została zamieszczona (podobnie jak pozostałe regulacje implementujące dyrektywę) w kodeksie cywilnym (zob. art. 6:162 i n. tego kodeksu). Na szczególną uwagę w kontekście tej instytucji zasługuje wszak wyrok w sprawie

\footnotetext{
39 Jakkolwiek przesłanka podobieństwa rynków - pomijając jej niejednoznaczny charakter - nie stanowi warunku stosowania zarzutu passing-on (zarówno „ofensywnie”, jak i „defensywnie”). Warunek taki nie wynika z dyrektywy.

40 Products or services containing them or derived therefrom; zob. art. 2 pkt 24 DD; polska definicja zob. art. 2 pkt 14 urns stanowi w zasadzie wierne tłumaczenie definicji legalnej nabywcy pośredniego jaka zawarto w cytowanym przepisie dyrektywy.

41 Jak wskazała Komisja, sytuacja w której występuja „różne szczeble łańcucha produkcji lub dystrybucji” (different level of the production or distribution chain), „oznacza na przykład że jedno przedsiębiorstwo produkuje surowiec, który drugie przedsiębiorstwo używa jako nakład bądź też pierwsze jest producentem, drugie hurtownikiem, a trzecie detalistą" (means for instance that one undertaking produces a raw material which the other undertaking uses as an input, or that the first is a manufacturer, the second a wholesaler and the third a retailer (...); [podkreślenie moje, K.K.] pkt 25 lit. c wytycznych Komisji w sprawie ograniczeń wertykalnych (2010/C 130/01) (Dz. Urz. UE C 130 z 19.05.2010, s. 1).
} 
Tennet ${ }^{42}$ (holenderski operator sieci przesyłowej). W wyroku tym zasądzone zostało jedno z najwyższych odszkodowań w Europie tytułem naprawienia szkody antymonopolowej. Co wszak kluczowe w kontekście tematyki tego opracowania, sąd nie zaakceptował podniesionego przez pozwanego ABB - spółkę zajmującą się produkcją izolacji gazowej (uczestnika kartel stwierdzonego przez Komisję ${ }^{43}$ ) - zarzutu passing-on, mimo wskazania przezeń, iż powód prawdopodobnie przerzucił nadmierne obciążenie na swych klientów (spółki sprzedające/dystrybuujące - zwłaszcza lokalnie - energię elektryczną), którzy z kolei przerzucili je na konsumentów końcowych. Sąd uznał, że ta ostatnia grupa podmiotów była bardzo liczna, a ich szkody rozdrobnione (,indywidualnie”) i tym samym niskie, co stwarzało znikome prawdopodobieństwo, że wystąpią oni z roszczeniami odszkodowawczymi (pomijając jeszcze inne bariery proceduralno-dowodowe). Uwzględnienie w danej sprawie zarzutu passing-on prowadziłoby zatem do faktycznego uniknięcia cywilnoprawnej odpowiedzialności antymonopolowej przez pozwanego członka kartelu (ABB) i tym samym jego bezpodstawnego wzbogacenia (Kohutek, 2018, s. 124-127).

2. Sprawa Tennet jest o tyle warta uwagi, iż ukazuje przypadek „elastycznego” podejścia do interpretacji (warunków skutecznego zastosowania) instytucji passing-on. Wyrażona w niej argumentacja jest zarazem korzystna dla tych poszkodowanych, którzy są bezpośrednimi nabywcami sprawcy naruszenia, mogąc przyczynić się do zwiększania bodźców do wytaczania pozwów odszkodowawczych (i tym samym zwiększenia skuteczności private enforcement). Nie powinny bowiem zachodzić wątpliwości, iż możliwość defensywnego podniesienia zarzutu passing-on nie tylko wydłuża i komplikuje proces, lecz także (w razie jego uwzględnienia przez sąd) może prowadzić do zredukowania odszkodowania (lub w ogóle podważenia zasadności całego pozwu). Jest zatem czynnikiem demotywującym nabywców bezpośrednich do dochodzenia roszczeń o naprawienie szkody antymonopolowej. Statystycznie zaś podmioty te najczęściej występują ze stosownymi pozwami (Lianos, Davis i Nebbia, 2011, s. 5, 73) (mając zazwyczaj - jako kontrahent sprawcy naruszenia - relatywnie „łatwiejszą sytuację dowodową” od innych poszkodowanych). Nabywcy bezpośredni należą więc do grupy najbardziej efektywnych podmiotów wdrażających prawo antymonopolowe w trybie prywatnym (tzw. private enforcers). Z tej perspektywy stanowisko sądu holenderskiego w sprawie Tennet zasługuje na aprobatę. Nie przywiązuje ono zbyt dużej (wręcz równowartościowej z celem, jakim jest wzrost efektywności private enforcement) wagi do konieczności unikania ryzyka bezpodstawnego wzbogacania po stronie nabywców bezpośrednich wskutek zasądzenia na ich rzecz nadmiernego odszkodowania (overcompensation), a słusznie koncentruje się na innym (w mojej opinii bardziej wartościowym; zob. szerzej: Kohutek, 2020) celu samej dyrektywy, jakim jest wykluczanie (lub minimalizowanie) przypadków w jakich sprawca naruszenia w ogóle nie poniesie odpowiedzialności (zob. art. 12 ust. 1 in fine DD). Także w doktrynie można spotkać się z podobnym stanowiskiem (Kersting, 2018, s. 152).

\footnotetext{
42 Wyr. holenderskiego sądu rejonowego w Gelderland z 29.03.2017 r., Tennet TSO BV, Saranne BV/ABB BV, ABB Ltd.

43 Dec. Komisji z 24.01.2007 r. w sprawie COMP/F/38.899, Gas Insulated Switchgear.
} 


\section{Polska}

\section{Uwagi ogólne (przepisy ustawy)}

W polskim prawie ustawa odszkodowawcza normuje jedynie ofensywny aspekt stosowania passing-on, czyli przez nabywcę pośredniego podnoszącego, że szkoda została na niego przerzucona. Artykuł 4 ust. 1 urns ustanawia domniemanie przerzucenia nadmiernego obciążenia na nabywcę (przy czym wyraźnie zastrzeżono, iż na domniemanie to może powołać się tylko nabywca pośredni; art. 4 ust. 2 urns). Przytoczone przepisy implementują do naszego prawa rozwiązanie zawarte w art. 14 DD. Polski ustawodawca nie zamieścił unormowania, które stanowiłoby wprost o korzystaniu z zarzutu passing-on w ramach obrony pozwanego w procesie odszkodowawczym (o takim aspekcie tego zarzutu stanowi art. 13 DD). W doktrynie brak zawarcia w ustawie uregulowania, które korespondowałoby z treścią powołanego przepisu dyrektywy ocenia się negatywnie, zwracając uwagę, iż jego wprowadzenie zwiększyłoby transparentność i skuteczność rozwiązań dyrektywy (Bernatt i Gac, 2018, s. 298).

W istocie w dużej ilości porządków krajowych państw członkowskich - i to nawet tych, w których dotychczasowe (tj. wydane w czasie sprzed uchwalenia dyrektywy) orzecznictwo wskazywało na dopuszczalność takiej obrony - prawodawca zdecydował się na wyraźne transponowanie rozwiązania z art. 13 DD.

Brak ustanowienia w przepisach polskiej ustawy unormowania, które expressis verbis normowałoby defensywne stosowania zarzutu passing-on nie może zarazem być interpretowane jako niedopuszczalność korzystania z tego rodzaju "obrony” przez pozwanego w procesie o naprawienie skody. Dopuszczalność taka wynika z zasad ogólnych procedury cywilnej ${ }^{44}$ (znajdując nadto potwierdzenie w krajowym orzecznictwie; zob. niżej). Poza tym stanowisko (rozwiązanie) przeciwne byłoby niezgodne z dyrektywą ${ }^{45}$.

\section{Sprawa kartelu cementowego: „rekompensata” wzrostu cen kartelowych}

2.1. W Polsce wydano bardzo niewiele wyroków, które można zakwalifikować - stricte - jako rozpatrujące pozwy odszkodowawcze za wyrządzenie szkody antymonopolowej. Wedle mojej wiedzy aktualnie są tylko dwa takie wyroki ${ }^{46}$. W wyroku w sprawie kartelu cementowego ${ }^{47}$ problematyka przerzucenia nadmiernego obciążenia została dostrzeżona przez sam Sąd Apelacyjny. Sąd ów wskazał, iż „powód uważa, że jego szkoda, wyraża się wyłącznie w różnicy cen zakupu cementu w poszczególnych okresach. Tymczasem nie można wykluczyć, że powód rekompensował sobie ten wzrost, podnosząc cenę odsprzedaży, a faktyczną szkodę ponieśli klienci budujący domy i inne obiekty" [podkreślenie moje, K.K.]. Na podstawie cytowanego stwierdzenia sądu można poczynić następujące uwagi.

2.2. Po pierwsze, z cytowanego fragmentu wyroku wynika niejako sama istota instytucji passing-on (choć literalnie nie zostało to tak określone przesz sąd). Sąd Apelacyjny zwrócił uwagę

45 Niezależnie od tego, że w mojej opinii przyjęte w niej rozwiązanie w zakresie instytucji passing-on - zwłaszcza stosowanej defensywnie - zasługuje na krytykę; zob. Kohutek, 2020.

46 Tj. po pierwsze, wyr. SO w Lublinie z 4.07.2014 r., I C 759/08, LEX nr 1845524 (sprawa odszkodowania za szkodę wyrządzona przez - stwierdzonej w decyzji Prezesa UOKiK - nadużycia pozycji dominującej poprzez odmowę dostępu do polerów cumowniczych na Wiśle; oraz po drugie, wyr. w sprawie kartelu cementowego (którego relewantne aspekty są omawiane w ramach tego opracowania); zob. przypis niżej.

47 Wyr. SA w Krakowie z 10.01.2014 r. I ACa 1322/13. Zawarcie tego kartelu zostało stwierdzone w decyzji Prezesa UOKiK z dnia 8.12.2009 r. nr DOK-7/09.
} 
na możliwość zredukowania (być może nawet w całości) straty powoda (polegającej na zapłacie zawyżonej - wskutek kartelu - ceny cementu, w jaki zaopatrywał się u członka kartelu) poprzez „zrekompensowanie” tejże straty dzięki podwyżce cen przez powoda cementu, jaki zbywał na rzecz własnych klientów. W mojej ocenie można zatem konkludować, iż cytowany wyrok - odnoszący się zarazem do roszczeń odszkodowawczych za szkodę antymonopolową (tu: kartelową) - potwierdza możliwość zastosowania w polskim porządku prawnym instytucji przerzucenia nadmiernego obciążenia (w rozumieniu art. 2 pkt 11 urns) na własnych klientów (nabywców pośrednich, mogących być zarazem konsumentami finalnymi ${ }^{48}$ ).

Po drugie, z cytowanego stwierdzenia Sądu Apleacyjnego można by dedukować, iż ciężar wykazania, że w danym przypadku nie doszło do przerzucenia nadmiernego obciążenia (w części lub w całości) spoczywa na powodzie. Sąd ów bowiem zdaje się kwestionować stanowisko powoda, który uważa że jego „szkoda, wyraża się wyłącznie w różnicy cen zakupu cementu w poszczególnych okresach"; tym samym ze stanowiska sądu wynika - skierowany do powoda - zarzut, iż niejako on sam nie odniósł się do faktu braku „rekompensaty” tejże szkody poprzez brak podwyżek własnych cen (czyli tym samym nie wykazał tej okoliczności). W obecnym stanie prawnym taki rozkład ciężaru dowodowego byłby niedopuszczalny, gdyż sprzeczny z dyrektywą odszkodowawczą (należy wszak mieć na uwadze, że omawiany wyrok wydany został prawie rok przed jej uchwaleniem). Jak to bowiem wprost wskazano w art. 13 zd. 2 DD, „ciężar dowodu, że nadmierne obciążenie zostało przerzucone, spoczywa na pozwanym" (the burden of proving that the overcharge was passed on shall be on the defendant). Także w polskiej doktrynie (mimo braku literalnego uregulowania defensywnego aspektu powoływania się na passing-on w przepisach urns) powszechnie wskazuje się, że ciężar udowodnienia faktu, iż powód dopuścił się (całościowego lub częściowego) przerzucenia nadmiernego obciążenia na własnych klientów, spoczywa na pozwanym (Turno, 2018, s. 170; Drzewiecka i Gulińska 2018, s. 112).

\subsection{Powyższe oznacza, że de lege lata powód może poprzestać na wykazaniu, iż jego} szkoda - mająca postać szkody kartelowej - stanowi nadmierne obciążenie (w rozumieniu art. 2 pkt 11 urns; zob. niżej), tj. polega właśnie na samej różnicy cen między towarem, jaki zakupił od członka kartelu a ceną, jaka obowiązywałaby za ów towar w przypadku braku kartelu. Jest to bowiem wykazanie, że poniósł szkodę. Nadmierne obciążenie niewątpliwie stanowi rodzaj szkody antymonopolowej (Turno, 2018, s. 125; Kohutek, 2018, s. 20). Wobec jednoznacznego przesądzenia, iż to pozwany w ramach swej obrony może powołać się na zarzut przerzucenia nadmiernego obciążenia, to tym samym to on (pozwany) ma obowiązek udowodnić, że takie przerzucenie faktycznie miało miejsce oraz w jakiej wysokości (znajduje to wyraźne potwierdzenie w treści samej dyrektywy ${ }^{49}$ ). Jeśli to udowodni, wówczas wysokość szkody (odszkodowania jakiego domaga się powód) będzie stosownie zredukowana (chyba że powód wykaże, że dodatkowo poniósł szkodę w postaci utraconych korzyści wskutek wspomnianego wyżej volume effect). Poza tym pomocniczo - na poparcie prezentowanego tu stanowiska - warto przytoczyć zawarte w dyrektywie domniemanie, iż naruszenia kartelowe (cartel infringements) wyrządzają szkodę

\footnotetext{
48 W danej sprawie nabywcami takimi mogli być zarówno inny przedsiębiorcy (jak zwłaszcza firmy deweloperskie), jak też konsumenci finalni (tj. podmioty nabywające cement $w$ celu wybudowania własnego domu - na użytek prywatny, tj. niezwiązany z działalnością gospodarczą - o ile w ogóle taką prowadzili). 49 Zob. motyw 39 zd. 3 preambuły do dyrektywy, który stanowi, iż „należy zapewnić, by sprawca naruszenia, jeżeli podnosi zarzut przerzucenia obciążeń, musiał dowieść istnienia i zakresu przerzucenia nadmiernego obciążenia" (is appropriate to provide that the infringer, in so far as it invokes the passing-on defence, must prove the existence and extent of pass-on of the overcharge); podkreślenie moje K.K.
} 
(zob. art. 17 ust. 2 DD), które to domniemanie zostało w polskim porządku prawnym poszerzone na wszelkie naruszenia prawa antymonopolowego (zob. art. 7 urns).

Reasumując, stwierdzić należy, iż powód nie musi w treści powództwa „informować sądu” o tym, czy w ogóle (a jeśli tak to w jakim zakresie) przerzucił nadmierne obciążenie na swych klientów. Wystarczające jest - jako dowód udowodnienia wysokości szkody - wskazanie przez powoda różnicy między ceną, jaką faktycznie płacił dostawcy (sprawcy naruszenia/pośrednikowi) za towar (usługę) a ceną, jaką prawdopodobnie by płacił w przypadku braku naruszenia (co bynajmniej nie przesądza, że odszkodowanie odpowiadające kwocie takiej szkody - wspomnianej różnicy - zostanie zasądzone ${ }^{50}$ ). Trudność dowodowa po stronie powoda sprowadzać się zatem będzie właśnie do prawidłowej (przekonującej dla sądu) identyfikacji ceny hipotetycznej („konkurencyjnej") - tzw. competitive price - tj. takiej, jaka by obowiązywała w razie braku naruszenia (zawarcia kartelu), w tym zwłaszcza ukazaniu, w jakim zakresie sam kartel (inne naruszenie prawa konkurencji) miał/miało wpływ na taką właśnie podwyżkę (a w jakim inne czynniki rynkowe - o ile wystąpiły); na co zwracał trafnie uwagę niemiecki Trybunał Federalny; zob. wyżej pkt II).

\section{Sprawa opłat za dostęp do infrastruktury kolejowej: zarzut passing-on „zwerbalizowany” w polskim orzecznictwie}

Warto przywołać tu jeszcze jedno orzeczenie, w którym wprost (nawet literalnie) powołano się na zarzut passing-on. Co prawda dana spawa nie dotyczyła odszkodowania za szkodę wynikającą z naruszenia prawa konkurencji, a polegała na obciążeniu powódki zawyżonymi opłatami za użytkownie infrastruktury kolejowej (gdyż skalkulowanymi w oparciu o nieprawidłową implementację przepisów stosownej dyrektywy ${ }^{51}$ ). W danej sprawie pozwanym był Skarb Państwa, a powódka domagała się zapłaty kwoty ponad 962 mln zł, która odpowiadała szacunkowej różnicy między tym, co zapłaciła tytułem wspomnianych opłat, a tym, co zapłaciłaby, gdyby stawki tych opłat ustalano zgodnie z prawem unijnym, tj. gdyby implementacja przepisów dyrektywy nastąpiła w sposób prawidłowy.

W powołanej sprawie jedną z istotnych okoliczności, jakie zostały podniesione przez pozwaną, był cyt.: „fakt, iż całość kosztów poniesiona przez powoda z tytułu dostępu do infrastruktury kolejowej została z jednej strony pokryta przez odbiorców usług świadczonych przez powoda (zarzut passing-on)"52. Sąd nie potraktował tego zarzutu jako niedopuszczalnego (ze względów merytorycznych, systemowych), jakkolwiek nie uwzględnił go z przyczyn dowodowych, uznając go za cyt. „nietrafny o tyle, że pozwany poza gołosłownym zarzutem nie przedstawił żadnego dowodu na jego potwierdzenie, wskazując tylko, że powódka nie poniosła straty na swej działalności, więc musiała przerzucić ciężar opłat ponoszonych na rzecz zarządcy infrastruktury na swych klientów". Z cytowanego fragmentu wynika więc także niejako potwierdzenie przez Sąd Apelacyjny okoliczności, iż ciężar dowodu na to, że powód nie poniósł szkody (względnie poniósł ją w mniejszym rozmiarze) spoczywa na pozwanym (zatem tak jak to wprost wskazano

\footnotetext{
50 Kwota ta ulegnie (a z pewnością może ulec zmianie) w razie skutecznego podniesienia przez sprawcę naruszenia zarzutu passing-on i/lub dochodzenia przez powoda szkody wynikającej ze spadku sprzedaży po jego stornie (z uwagi na podwyżki własnych cen jakich dokonał przerzucając nadmierne obciążenie na swych klientów).

51 W danej sprawie chodziło o dyrektywę Parlamentu Europejskiego i Rady z dnia 26 lutego 2001 r. w sprawie alokacji zdolności przepustowej infrastruktury kolejowej i pobierania opłat za użytkowanie infrastruktury kolejowej oraz przyznawania świadectw bezpieczeństwa.

52 Wyr. SA w Warszawie z 21.06.2018 r., I ACa 105/17 (www.orzeczenia.waw.sa.gov.pl).
} 
w art. 13 zd. 2 DD). W danej sprawie ostatecznie apelacja została oddalona - a odszkodowanie nie zostało zasądzone.

Warto jeszcze odnieść się do innego argumentu sądu (przytoczonego przez Sąd Apelacyjny - jakkolwiek dostrzeżonego przez sąd rozpatrujący tę sprawę w pierwszej instancji), z którego wynika, iż opłacalność usług, z jakich poszkodowany korzystał na mocy umowy z pozwanym, miałaby przemawiać jako okoliczność podważająca zasadność odszkodowania na rzecz tego pierwszego ${ }^{53}$. Argument taki - w kontekście ram prawnych dochodzenia naprawienia szkody antymonopolowej - jest chybiony. Prowadzenie biznesu nierentownego, tj. wykazywanie strat w sprawozdaniach finansowych (nawet jeśli ich głównym - a nawet jedynym - powodem było kontraktowanie ze sprawcą naruszenia prawa konkurencji) nie jest warunkiem zasądzenia odszkodowania.

\section{Refleksje końcowe}

1. W zasadzie w każdym z państw członkowskich, w których model prywatnego wdrażania prawa konkurencji był już wystarczająco rozwinięty (jeszcze przed implementacją dyrektywy), sądy aprobowały możliwość powoływania się na zarzut passing-on (zazwyczaj jako obronę przez pozwanego, a rzadziej w ramach jego ofensywnego stosowania, tj. przez nabywców pośrednich). W Polsce - jak to wynika z argumentacji Sądu Apelacyjnego (w sprawie kartelu cementowego) dostrzega się problematykę przerzucania nadmiernego obciążenia przez ofiarę naruszenia prawa konkurencji (jakkolwiek takim terminem sąd ów się nie posłużył, wspominając o możliwości „zrekompensowania" sobie przez ów podmiot szkody poprzez podniesienie własnych cen).

Pewne różnice w judykaturze sadów państw członkowskich przejawiały się w rozkładzie obowiązku dowodowego ciążącego na podmiocie powołującym się na zarzut passing-on (mógł być to zarówno powód - mający wykazać brak dokonania takiego przerzucenie bądź tez pozwany). Obecnie wszak wskazany problem rozwiązuje dyrektywa (ciężar ów spoczywa na pozwanym - co z resztą w znacznej części unormowań krajowych implementujących dyrektywę wprost zostało przewidziane; jednym z wyjątków jest w tej materii polska ustawa).

2. W ramach uwag końcowych warto także postawić pytanie, czy harmonizacja unormowań dotyczących passing-on doprowadzi do stworzenia faktycznie jednolitych (lub choćby podobnych) warunków sądowego egzekwowania roszczeń odszkodowawczych w państwach członkowskich i tym samym zredukowania zjawiska forum shopping. Wydaje się wszakże, iż kluczową rolę w tym zakresie nadal odgrywać będzie judykatura krajowa, a pozwy odszkodowawcze częściej będą (mogą być) składane w tych państwach, w których sądy przejawiają skłonność do wąskiego (czy wręcz restrykcyjnego) podejścia przy uwzględnianiu zarzutu passing-on podnoszonego przez sprawcę naruszenia. Mając więc na uwadze powołane w ramach tego opracowania orzeczenia, w pierwszej kolejności należałoby tu wymienić holenderski wyrok w sprawie Tennet, w którym sąd nie uwzględnił tego zarzutu, mimo że nie podważono faktu, iż powodowa spółka prawdopodobnie przerzuciła nadmierne obciążenie na swych klientów (konsumentów końcowych). Również argumentacja przyjęta w przez niemiecki sąd w sprawie Göttingen (tym bardziej o ile zostanie utrzymana przez sądy wyższych instancji) zwiększa motywacje powodów (będących jednostkami

Zdaniem Sądu Apelacyjnego (cyt.): „przechodząc do rozważań dotyczących szkody Sąd pierwszej instancji wskazał, iż zgodnie z zasadą volenti non fit iniuria (chcącemu nie dzieje się krzywda), powódka podejmując decyzję o korzystaniu z usług pozwanego (...) w zakresie dostępu do infrastruktury kolejowej kalkulowała opłacalność tego interesu znając wysokość stawek za korzystanie z tej infrastruktury. Sprawozdania finansowe za poszczególne okresy nie wykazują, aby ponosiła ona stratę netto, nie wykazała też w żaden sposób, że umowy te były dla niej nieopłacalne".

internetowy Kwartalnik Antymonopolowy i Regulacyjny 2020, nr 3(9) • www.ikar.wz.uw.edu.pl • DOI: 10.7172/2299-5749.IKAR.3.9.6 
samorządu terytorialnego) do składania stosownych pozwów odszkodowawczych z uwagi na zredukowanie ryzyka ich oddalenia w oparciu o zarzut passing-on.

3. Jak dotychczas nie zostały wydane wyroki (w szczególności przez sądy krajowe wyższych instancji), w których byłyby już zastosowane unormowania przepisów implementujących rozwiązania z dyrektywy odszkodowawczej, w tym te dotyczące problematyki passing-on (nierzadko powodem tego była także okoliczność, iż szkoda powstała w okresie, w jakim przepisy te albo w ogóle jeszcze nie obowiązywały albo nie miały zastosowania, zatem w danej sprawie brak było podstaw do ich powoływania). Warto dodać, iż pozwy follow-on (zob. przypis nr 31) w sprawach karteli stwierdzonych przez Komisję (jak np. sprawa Air Cargo, sprawa chlorku litu, sprawa wosku parafinowego czy też kartel ciężarówek) odnosiły się (z nieznacznymi wyjątkami dotyczącymi tego ostatniego kartelu) do szkód (i naruszeń), jakie miały miejsce jeszcze przed uchwaleniem dyrektywy (Classen i Seegers, 2019, s. 20). Mimo to w ostatnim czasie (zwłaszcza od 2016/2017 r., czyli także „w okresie 'przedimplementacyjnym'”54) odnotowuje się wzrost korzystnych rozstrzygnięć w procesach o naprawienie szkody antymonopolowej (tj. albo zasądzenie odszkodowania, albo stwierdzenie odpowiedzialności pozwanego). O ile tak właśnie rozumiany współczynnik skuteczności pozwu w latach 2013-2014 mieścił się pomiędzy 39-43\%, o tyle w okresie 2017-2018 oscylował już wokół 78-80\% (kalkulacja ta dotyczy 28 państw członkowskich, przy czym najwięcej korzystnych rozstrzygnięć dla ofiar naruszeń prawa konkurencji zapadło we Francji i w Niemczech (Laborde, 2018, s. 4, 5). Jeśli zatem weźmie się pod uwagę fakt, iż rozwiązania dyrektywy mają zwiększyć bodźce do dochodzenia naprawienia szkód antymonopolowych przed sądem (względnie w drodze ugody), można zatem przyjmować, iż ów trend powinien jeszcze wzrosnąć (a „co najmniej" się utrzymać). Jakkolwiek trudno w tym zakresie dokonywać jednoznacznych założeń, tym bardziej w odniesieniu do takich państw, jak Polska (czyli tych, w których dotychczas model prywatnego wdrażania reguł antymonopolowych był słaby rozwinięty - zwłaszcza w wymiarze dorobku judykatury).

\section{Bibliografia}

Ashton, D. (2018). Competition Damages Actions in the EU. Law and Practice (sec. ed.). Northampton: Cheltenham.

Bernatt, M. i Gac, M. (2018). W: B. Rodger, M.S. Ferro, F. Marcos (red.), The EU Antitrust Damages Directive. Transposition in the Member States. Poland. Oxford: Oxford University Press.

Bishop, S. i Walker, M. (2010). The Economics of EC Competition Law. Concepts, Application and Measurements. London: Sweet \& Maxwell.

Classen, U. i Seegers, M. (2019). The State of Private Enforcement of Competition Law: A Pracitioner's Perspective. W: M. Strand, V. Bastidas, M.C lacovides (red.), EU Competition Litigation. Transposition and First Experiences of the New Regime. Oxford, New York, New Delhi, Sydney: Hart Publishing. Contreras, M. (2019, March 22). Availability Of The Passing-On Defence In Private Antitrust Litigation in Spain. Oxford Competition Law. Pozyskano z: https://oxcat.ouplaw.com/page/762).

Drzewiecka, K. i Gulińska, A. (2018). W: K. Lis-Zarrias, P. Machnikowski (red.), Ustawa o roszczeniach o naprawienie szkody wyrządzonej przez naruszenie prawa konkurencji. Warszawa: C.H. Beck.

\footnotetext{
54 Dyrektywa odszkodowawcza miała zostać implementowana do porządków krajowych do dnia 27 grudnia 2016 r. (art. 21 ust. 1 DD). Relatywnie sporo państw członkowskich (w tym Polska) dokonało wszak implementacji po tym terminie.
} 
Kersting, C. (2018). W: B. Rodger, M.S. Ferro, F. Marcos (red.), The EU Antitrust Damages Directive. Transposition in the Member States. Germany. Oxford: Oxford University Press.

Kohutek, K. (2018). Szkoda antymonopolowa. Zasady odpowiedzialności i dochodzenia roszczeń odszkodowawczych. Warszawa: Wolters Kluwer.

Kohutek, K. (2019). Odpowiedzialność odszkodowawcza przedsiębiorcy kontynuującego działalność gospodarczą sprawcy naruszenia prawa konkurencji. Glosa do wyroku TSUE z 14.3.2019 r. w sprawie C-724/17 Vantaan kaupunki v. Skanska Industrial Solutions. Europejski Przegląd Sądowy, 6.

Kohutek, K. (2020). Obrona passing-on w procesie naprawienia szkody antymonopolowej: analiza krytyczna na tle dyrektywy unijnej, orzecznictwa oraz instytucji prawa cywilnego. Transformacje Prawa Prywatnego. W druku.

Kaszubski, R. i Obsejda, Ł. (2012). Karty płatnicze w Polsce. Warszawa: Wolters Kluwer business LEX. Kulikowska-Wielgus, A. (2019). More judgements on compensation for collusion between truck manufacturers. Trans.info. Pozyskano z: https://trans.info/en/judgements-on-compensation-for-collusion-between-truckmanufacturers-132319.

Laborde, J.-F. (2018). Cartel damages actions in Europe: How courts have assessed cartel overcharges. Law \& Economics I Concurrences, 1-2019, Pozyskano z: www.concurrences.com.

Lianos, I., Davis, P. i Nebbia, P. (2011). Damages claims for the infringement of EU competition law. Oxford: Oxford University Press.

Turno, B. (2018). W: A. Piszcz, A. Stawicki, D. Wolski (red.), Roszczenia o naprawienie szkody wyrządzonej przez naruszenie prawa konkurencji. Komentarz. Warszawa: Wolters Kluwer.

Wieczorek, Ł. (2013). Zarzut przerzucenia obciążeń w kontekście prywatnoprawne wdrażania prawa konkurencji w Unii Europejskiej. Przegląd Prawa Handlowego, 4.

Veljanovski, C (2017, January 21). The law and economics of pass-on in pricing fixing cases. European Competition Law Review, 1. Pozyskano z: www.ssrn.com.

Veljanovski, C. (2015, March). Volume effect damages in cartel cases Why pass-on gives rise to offsetting lost volume damages. Economics of Competition, Regulation and Litigation, 3. Pozyskano z: www. casecon.com. 